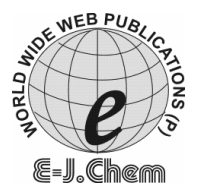

http://www.e-journals.net
CODEN ECJHAO

E-Journal of Chemistry

Vol. 3, No.1, pp 5-8, January 2006

\title{
A Note on the Estimation of Moxifloxacin in Bulk and Pharmaceutical Formulations by Precipitation Reagents
}

\author{
K.V.S. PARASADA RAO, L.D. SRINIVAS, P. RAVIKUMAR, \\ P.YESUPADAM and G.PRABHAKAR* \\ Pharmaceutical and Food Analysis Division, \\ Department of Pharmaceutical Sciences, Andhra University, \\ Visakhapatnam-530 003, India. \\ vsprk@yahoo.co.in
}

Received 8 September 2005; Accepted 23 January 2006

\begin{abstract}
Simple spectrphotometric methods for the assay of moxifloxacin based on the formation of its complexes with alkaloidal precipitants are described.
\end{abstract}

Key words:. Spectrophotometry, Alkaloidal precipitants, Moxifloxacin

\section{Introduction}

Alkaloids are detected with the aid of group of reactions due to their chemical properties, structure and presence of functional groups. These reactions are based on the ability of the alkaloid to yield insoluble complexes mainly with AM, $\mathrm{I}_{2}$ and PMA and hence these reagents are named as alkaloidal precipitants ${ }^{1}$. The precipitate is ascribed due to the formation of a molecular complex resulting from the interaction of the unshared electron on nitrogen in amine with an unoccupied molecular orbital of the alkaloidal precipitant molecule. Moxifloxacin ${ }^{2}$ (MOX) is an antibacterial agent chemically known as 1-cyclopropyl- 6- fluoro- 1,4- dihydro- 8- methoxy -7- ((4As,7As)) -octahydro -6Hpyrrolo (3,4-b)pyridin-6-yl)- 4-oxo-3-quinolinecarboxylic acid. Literature mentions a few methods such as HPLC ${ }^{3-5}$, LC-MS L $^{6,7}$ and spectroflurometry ${ }^{8}$ for its determination in biological fluids and dosage forms. The aim of the present work is to provide simple and sensitive visible spectrophotometric methods, for the estimation of MOX in bulk form and formulations. The effects in this accord resulted to develop the present methods. 


\section{Experimental}

Spectral and absorbance measurements were made on Systronics UV-Visible Spectrophotometer 117 with $10 \mathrm{~mm}$ matched quartz cells. All the chemicals and reagents used analytical grade and the solutions were freshly prepared. Aqueous solution of $\mathrm{I}_{2}$ $(0.089 \%)$ in $0.83 \%$ of potassium iodide (KI), PMAP $(2 \%)$, SAc $(0.4 \%)$, hydrochloric acid $(\mathrm{HCl})(1 \mathrm{M})$ for method $\mathrm{A}$; AM $(2 \%)$, PTC $(10 \%)$, con..HCl (used as it is) for method B; PMA (4\%) Co(II) (3\%), DETA (4\%) for method C, $0.01 \mathrm{M} \mathrm{HCl}$ for methods B and C were prepared in triple distilled water. A one $\mathrm{mg} / \mathrm{ml}$ solution was prepared by dissolving $100 \mathrm{mg}$ of pure MOX in $100 \mathrm{ml}$ of distilled water and this stock solution was diluted stepwise with distilled water to obtain the working standard solution of concentrations $400 \mu \mathrm{g} / \mathrm{ml}$ for method A, $100 \mu \mathrm{g} / \mathrm{ml}$ for method B and C respectively.

\section{Recommended Procedures \\ Method A}

Aliquots of working standard solution (MOX) $(0.5-2.5 \mathrm{ml}, 400 \mu \mathrm{g} / \mathrm{ml})$ were delivered into a series of centrifuge tubes and the volume in each tube was adjusted to $3.0 \mathrm{ml}$ with distilled water. Then $2.0 \mathrm{ml}$ each of $1 \mathrm{M} \mathrm{HCl}$ and $\mathrm{I}_{2}$ were added successively and centrifuged for 5 min. The precipitate was collected by filtration and subsequently washed with $2 \mathrm{ml}$ distilled water. The filtrate and washings were collected in $25 \mathrm{ml}$ graduated test tubes. Then $3.0 \mathrm{ml}$ of PMAP solution and $2.0 \mathrm{ml} \mathrm{SAc}$ solution were added successively and the volume was made up to the mark with distilled water. The absorbance was measured during next $30 \mathrm{~min}$. at $520 \mathrm{~nm}$ against distilled water. A blank experiment was also carried out omitting the drug. The decrease in absorbance and inturn drug concentration was obtained by subtracting the absorbance of the test solution from blank. The amount of drug was calculated from calibration graph.

\section{Method B}

Aliquots of working standard solution $(1.0-3.0 \mathrm{ml}, 100 \mu \mathrm{g} / \mathrm{ml})$ were delivered into a series of centrifuge tubes and the volume in each tube was adjusted to $3.0 \mathrm{ml}$ with $0.01 \mathrm{~m} \mathrm{HCl}$. Then $1.0 \mathrm{ml}$ of AM was added and centrifuged for $5 \mathrm{~min}$. The precipitate was collected by filtration followed by washing with $50 \%$ alcohol until it is free from the reagent. The precipitate in each tube was dissolved in $5.0 \mathrm{ml}$ of acetone and transferred into $25.0 \mathrm{ml}$ graduated tube. The $5 \mathrm{ml}$ of conc. $\mathrm{HCl}$ and $3 \mathrm{ml} \mathrm{PTC}$ solution were successively added and kept aside for $30 \mathrm{~min}$ and then volume in each tube was made up to the mark with distilled water. The absorbance was measured at $480 \mathrm{~nm}$ against a similar reagent blank. The amount of drug MOX was calculated form the calibration graph.

\section{Method C}

Aliquots of working standard solution $(0.5-2.5 \mathrm{ml}, 100 \mu \mathrm{g} / \mathrm{ml})$ were delivered into a series of centrifuge tubes and volume in each tube was adjusted to $3.0 \mathrm{ml}$ with $0.01 \mathrm{~m} \mathrm{HCl}$. The 2.0 ml PMA was added and centrifuged for 5 min. the precipitate was collected by filtration followed by washing with distilled water until it is free from the reagent. The precipitate in each tube was dissolved in $5 \mathrm{ml}$ of acetone and transferred into $25 \mathrm{ml}$ graduated tubes. One $\mathrm{ml}$ each of Co (II) and EDTA solutions were successively added and the tubes were heated for $15 \mathrm{~min}$. at $60^{\circ} \mathrm{C}$ in water bath. The tubes were cooled and the solution each tube was made up to the mark with distilled water. The absorbance was measured at $840 \mathrm{~nm}$ against a similar reagent blank. The amount of drug was calculated from its calibration graph. 


\section{Results and Discussion}

The optimum conditions for the color development of methods (A, B and C) were established by varying the parameters one at a time keeping the others fixed and observing the effect produced on the absorbance of the colored species.

The optical characteristics such as Beer's law limits; molar absorptivity and Sandell's sensitivity for each method (A-C) are given in table1. The precision of each method to the drug was found by measuring the absorbance of six separate samples containing known amounts of drug and the results obtained are incorporated in table1. Regression analysis using the method of least squares was made to evaluate the slope (b), intercept (a), correlation coefficient (r) and standard error of estimation $\left(S_{e}\right)$ for each system and is presented in Table1.

Table 1 Optical Characteristics, Precision and Accuracy of the proposed methods for MOX

\begin{tabular}{lccc}
\hline \multicolumn{1}{c}{ Parameters } & Method A & Method B & Method C \\
\hline$\lambda_{\max }(\mathrm{nm})$ & 520 & 480 & 840 \\
Beer's Law limits $(\mu \mathrm{g} / \mathrm{ml})$ & $3.5-24.0$ & $2.68-30$ & $1.0-10.0$ \\
$\begin{array}{l}\text { Molar absorptivity }\left(1 \mathrm{~mole}^{-1} \mathrm{~cm}^{-1}\right) \\
\text { Sandell's sensitivity }\end{array}$ & $6.25 \times 10^{3}$ & $8.16 \times 10^{3}$ & $1.99 \times 10^{4}$ \\
$\left(\mu \mathrm{g} / \mathrm{cm}^{2} / 0.001\right.$ absorbance unit) & & & \\
$\begin{array}{l}\text { Regression Equation y = a + bc* } \\
\text { Slope (b) }\end{array}$ & 0.071 & 0.054 & 0.023 \\
$\begin{array}{l}\text { Intercept (a) } \\
\text { Correlation coefficient (r) }\end{array}$ & 0.014 & 0.018 & 0.042 \\
$\begin{array}{l}\text { Relative Standard Deviation }(\%) * * \\
\text { \% Range of error ** }\end{array}$ & 0.0001 & 0.0006 & 0.002 \\
$\quad(0.05$ level confidence limit $)$ & 0.412 & 0.9999 & 0.9999 \\
\hline
\end{tabular}

$* \mathrm{Y}=\mathrm{a}+\mathrm{bc}$, where $\mathrm{c}$ is the concentration in $\mu \mathrm{g} / \mathrm{ml}$.

**From six determinations.

The accuracy of the methods was ascertained by comparing the results by proposed and reference methods (UV) statistically by $\mathrm{t}$ - and F-tests (Table 2). The comparison shows that there is no significant difference between the results of studied methods and those of reference ones. The similarity of the results is obvious evidence that during the application of these methods, the excipients that are usually present in pharmaceutical formulations do not interfere in the assay of proposed methods. As an additional check of accuracy of the proposed methods recovery experiments were carried out. The recovery of the added amounts of standard drug was studied at 3 different levels. Each level was repeated for 6 times. From the amount of drug found, the \% recovery was calculated in the usual way.

The higher $\lambda_{\max }$ values of all the proposed methods have a decisive advantage since the interference from the associated ingredients should be generally less at higher wavelengths than at lower wavelengths. Thus the proposed visible spectrophotometric methods are simple and sensitive with reasonable precision, accuracy and constitute better alternatives to the existing ones to the routine determination of MOX in bulk forms and pharmaceutical formulations. 
Table 2 Determination of MOX in pharmaceutical formulations

\begin{tabular}{|c|c|c|c|c|c|c|c|c|}
\hline \multirow{3}{*}{$\begin{array}{l}\text { Sample }^{\Delta} \\
\text { (Tablets) }\end{array}$} & \multirow{3}{*}{$\begin{array}{c}\text { Labeled } \\
\text { method } \\
(\mathrm{mg})\end{array}$} & \multirow{3}{*}{$\begin{array}{l}\text { UV* } \\
\text { Method }\end{array}$} & \multicolumn{3}{|c|}{ Amount obtained (mg) } & & \multirow[b]{2}{*}{ Recovery } & \multirow[b]{2}{*}{$(\%)$} \\
\hline & & & Prop & ed meth & & & & \\
\hline & & & A & B & $\mathrm{C}$ & A & B & $\mathrm{C}$ \\
\hline $\mathrm{T}_{1}$ & 400 & $\begin{array}{c}396.8 \\
\pm 1.864\end{array}$ & $\begin{array}{c}398.5 \\
\pm 1.77 \\
\mathrm{~F}=2.15 \\
\mathrm{t}=0.99\end{array}$ & $\begin{array}{c}399.2 \\
\pm 0.72 \\
\mathrm{~F}=1.34 \\
\mathrm{t}=1.86\end{array}$ & $\begin{array}{c}399.2 \\
\pm 1.34 \\
\mathrm{~F}=2.76 \\
\mathrm{t}=0.10\end{array}$ & $\begin{array}{c}99.6 \\
\pm 0.44\end{array}$ & $\begin{array}{c}99.8 \\
\pm 0.18\end{array}$ & $\begin{array}{c}99.8 \\
\pm 0.33\end{array}$ \\
\hline $\mathrm{T}_{2}$ & 400 & $\begin{array}{c}396.9 \\
\pm 0.695\end{array}$ & $\begin{array}{c}398.3 \\
\pm 1.73 \\
\mathrm{~F}=1.03 \\
\mathrm{t}=0.10\end{array}$ & $\begin{array}{c}399.9 \\
\pm 1.95 \\
\mathrm{~F}=1.83 \\
\mathrm{t}=1.86\end{array}$ & $\begin{array}{c}399.5 \\
\pm 0.89 \\
\mathrm{~F}=2.28 \\
\mathrm{t}=1.73\end{array}$ & $\begin{array}{c}99.6 \\
\pm 0.43\end{array}$ & $\begin{array}{c}99.9 \\
\pm 0.48\end{array}$ & $\begin{array}{c}99.8 \\
\pm 0.22\end{array}$ \\
\hline $\mathrm{T}_{3}$ & 400 & $\begin{array}{c}400.3 \\
\pm 2.668\end{array}$ & $\begin{array}{c}399.4 \\
\pm 2.65 \\
F=1.85 \\
t=1.99\end{array}$ & $\begin{array}{c}399.2 \\
\pm 0.72 \\
F=2.51 \\
t=1.73\end{array}$ & $\begin{array}{c}399.6 \\
\pm 0.67 \\
F=2.11 \\
t=1.94\end{array}$ & $\begin{array}{c}99.8 \\
\pm 0.66\end{array}$ & $\begin{array}{c}99.8 \\
\pm 0.18\end{array}$ & $\begin{array}{c}99.9 \\
\pm 0.16\end{array}$ \\
\hline $\mathrm{T}_{4}$ & 400 & $\begin{array}{c}398.9 \\
\pm 1.792\end{array}$ & $\begin{array}{c}399.0 \\
\pm 2.61 \\
F=2.03 \\
t=1.73\end{array}$ & $\begin{array}{c}399.6 \\
\pm 0.62 \\
\mathrm{~F}=1.28 \\
\mathrm{t}=1.86\end{array}$ & $\begin{array}{c}399.7 \\
\pm 1.95 \\
\mathrm{~F}=1.47 \\
\mathrm{t}=1.73\end{array}$ & $\begin{array}{c}99.8 \\
\pm 0.65\end{array}$ & $\begin{array}{c}99.9 \\
\pm 0.15\end{array}$ & $\begin{array}{c}99.9 \\
\pm 0.48\end{array}$ \\
\hline
\end{tabular}

${ }^{\Delta}$ Four different batches of tablets from a pharmaceutical company.

\section{Reference}

1. Melentyeva $\mathrm{G}$ and Antonova L, Pharmaceutical Chemistry, Mir Publishers, Moscow, 1988, 330.

2. The Merck Index , Merck and Co Inc, New York ,13 $3^{\text {th }}$ edn 1803 (2001).

3. Liang H R, Kays M B and Sowinski K M, J. Chromatogr. B. Anal. Techol. Biomed. Life Scie, 2002, 772(1), 53.

4. Ba, B B, Etienne R, Ducint D, Quentin C, and Saux, M.C, J. Chromatogr. B. Biomed. Appli, 2001, 754(1), 107

5. Lemoine J, Breilh D, Ducint D, Dubrez J, Jougon J, Velly J F and Saux M C , J. Chromatogr. B. Biomed. Appli, 2000, 742(2), 247.

6. Vishwanathan K, Bartlett M G and Stewart J T, J. Pharm. Biomed. Anal, 2002, 30(4), 961.

7. Zimmer D, Pickasd R, Czembor W and Muelles C, Chromatographia, 2000, 52, S26.

8. Ocano J A, Barragan F J and Callejon M, Analyst(U.K.), 2000, 125(12), 2322. 


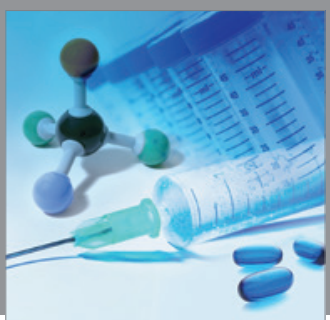

International Journal of

Medicinal Chemistry

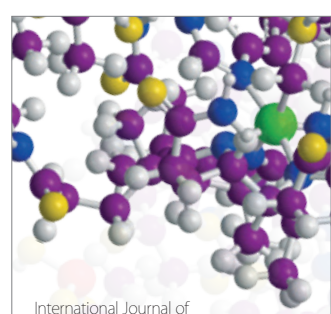

Carbohydrate Chemistry

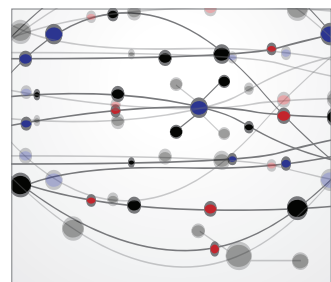

The Scientific World Journal
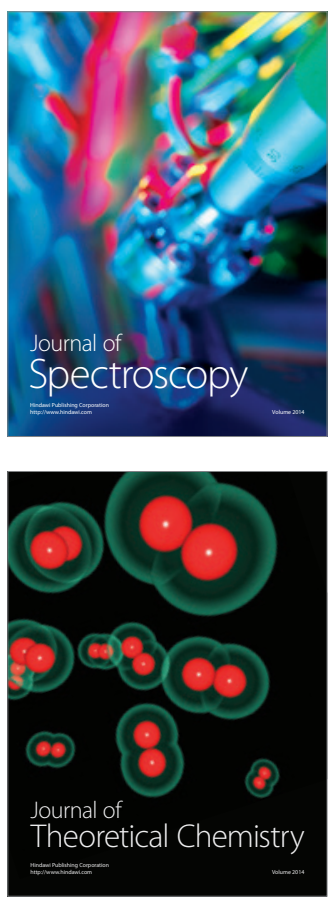
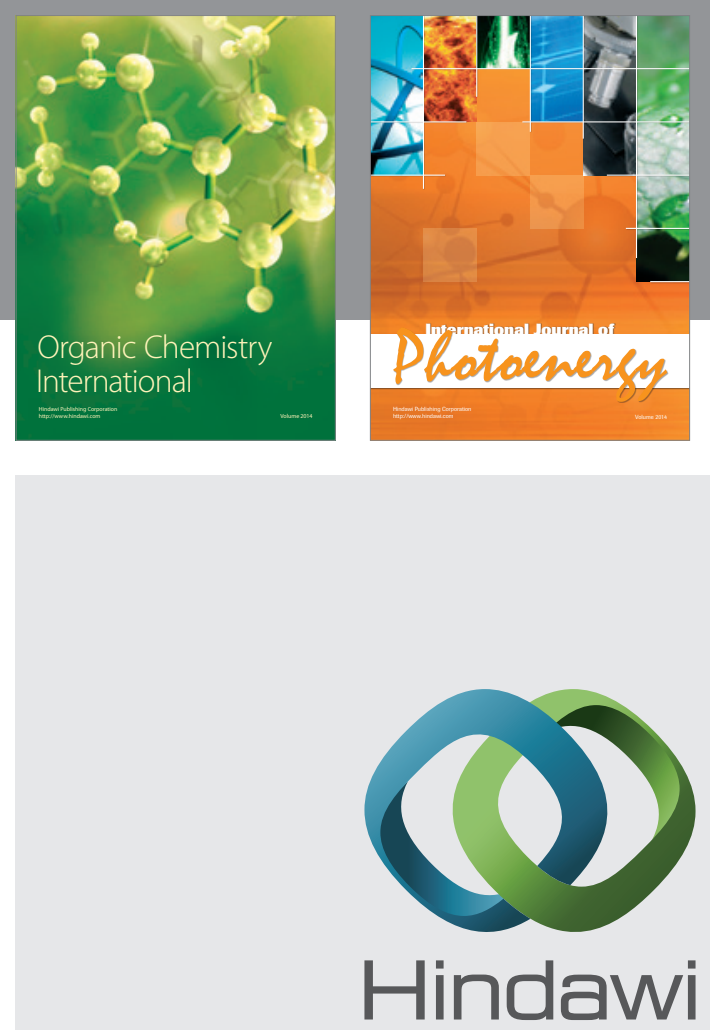

Submit your manuscripts at

http://www.hindawi.com
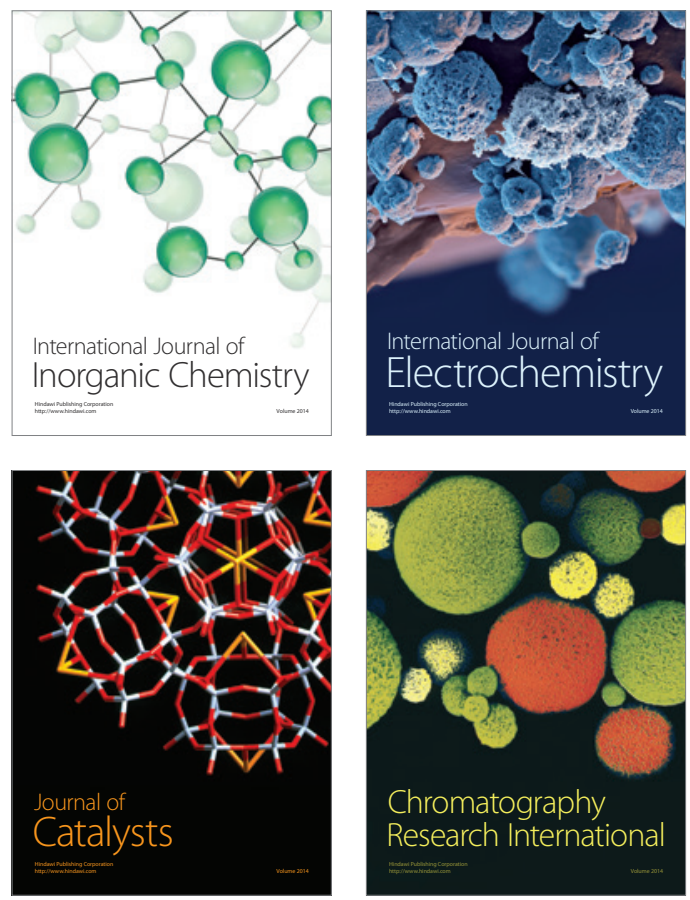
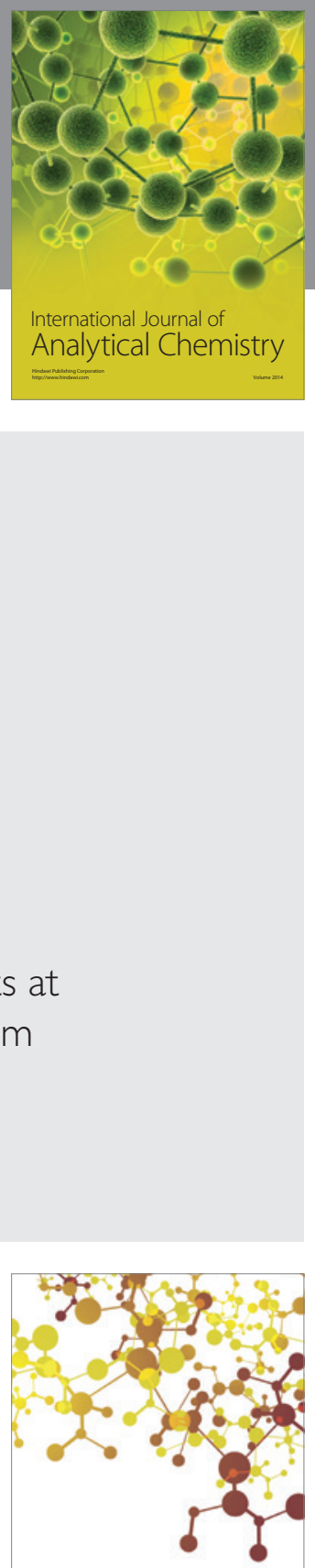

Journal of

Applied Chemistry
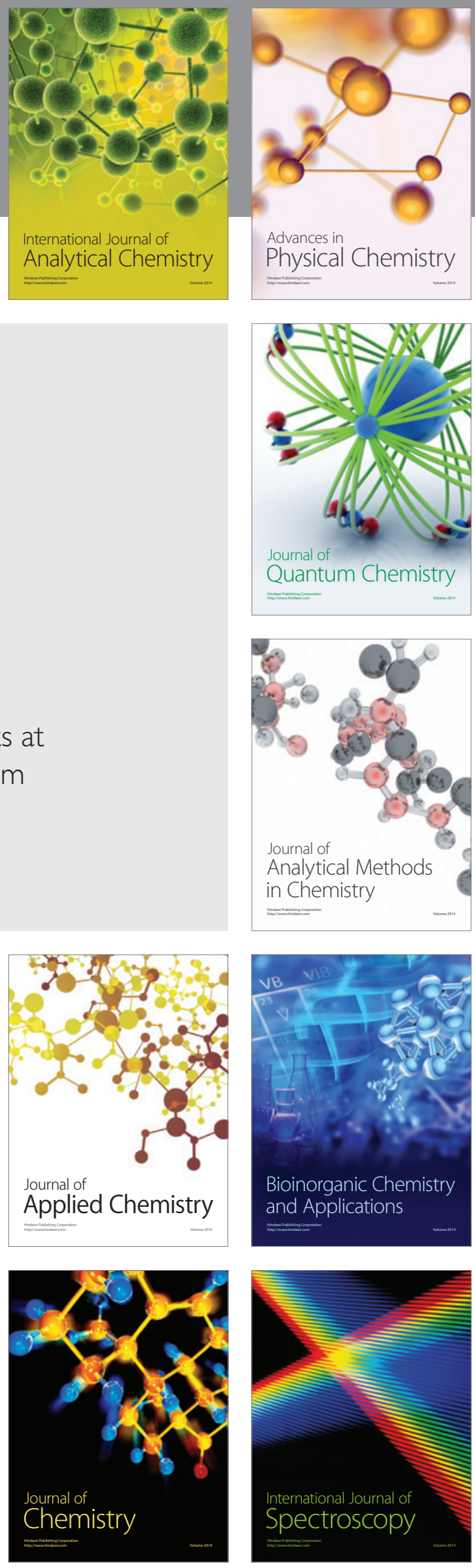